SAVELIEVA O. A.

Scientific and Technical Library, Dnipro National University of Railway Transport named after Academician V. Lazaryan (Dnipro, Ukraine), e-mail ojs.stp@gmail.com, ORCID 0000-00017670-4483

SAVINA O. P.

Scientific and Technical Library, Dnipro National University of Railway Transport named after Academician V. Lazaryan (Dnipro, Ukraine), e-mail savina.o.p@gmail.com,

ORCID 0000-0001-7872-6416

STEPANENKO V. M.

Scientific and Technical Library, Dnipro National University of Railway Transport named after Academician V. Lazaryan (Dnipro, Ukraine), e-mail ctepsvi.diit@gmail.com,

ORCID 0000-0003-2409-3769

VOITOVYCH O. V.

Scientific and Technical Library, Dnipro National University of Railway Transport named after Academician V. Lazaryan (Dnipro, Ukraine), e-mail olenka-a5@ukr.net

\title{
PROFILE OF THE SCIENTIFIC ORGANIZATION IN SCOPUS AND WEB OF SCIENCE DATABASES. THE ROLE OF UNIVERSITY LIBRARIES IN THE PRESENTATION OF THE PUBLICATION ACTIVITY OF SCIENTIFIC ORGANIZATION
}

Purpose. The article is aimed to prove the possibility of increasing the significance of university libraries through the services for representing the publication activity of a scientific organization. Methodology. Consideration of the possibilities of the university library to support the scientific and publishing activities of the university, namely its publication activity, was carried out on the experience of the Scientific and Technical Library of Dnipro National University of Railway Transport named after Academician V. Lazaryan (Library of DNURT). Results. The features and stages of creating / correction of the organization profile in Scopus and Web of Science databases are presented. The role of the library in scientometric studies evaluating the publication activity of university is indicated. Conclusions. The demand for university library and strengthening of its role have significantly increased as a result of the introduction of services to support the publication activity of employees and organization.

Keywords: organization profile; Scopus; Web of Science; Library of DNURT; publication support services; library services

\section{Introduction}

A modern university of international level is not so much an educational institution as a research centre that uses the intellectual potential of a team of teachers, researchers, employees of the university library (Myamlin \& Kolesnykova, 2014). The publication activity can be considered as the criterion for evaluating the labor efficiency of a research centre (laboratory, scientific organization as a whole) (Myrhorodska \& Savelieva, 2016). The task of correct evaluation of the publication activity of individual scientific-pedagogical and scientific employees is associated with the problem of correct evaluation of the scientific achievements of the university as a whole. And since this evaluation is becoming increasingly important for university reporting, which is associated with budget financing and other investments, the number of different indicators, both for the university and for individual scientists, is constantly 
growing. In order to cope with this task, scientometric research methods that to one degree or another describe the publication activity are used (Kvelidze-Kuznetsova \& Morozova, 2009; Kolesnykova \& Matveyeva, 2015). The results of these studies affect the university position, both in the Ukrainian and in international ratings, which is also very important in the modern realities of higher education development in Ukraine. University libraries are playing an increasing role in these information-analytical processes. But since the services of diverse library support for scientific research are constantly changing and becoming more complicated, this issue is in the focus of attention of librarians.

\section{Literature analysis.}

Today, academic libraries of different countries offer specialized services to members of the scientific communities of their institutions, which include the active mediation of librarians during the preparation, distribution and analysis of the results of scientific work. New services require structural changes, for example, the creation of information analytics service (IAS) as a tool for monitoring the global scientific information flow, analysis of the citation level of university scientists and the impact indices of its periodicals in the international scientific information space, etc. (Kolesnykova, 2016). Among the services of information analytics are creating and organizing university profiles for Scopus and Web of Science databases, as well as helping scientists to create author profiles in Scopus, Google Scholar, bibliographic managers and specialized social networks, author identifier registers ResearcherID and ORCID (ibid.).

The Durham University Library website (Durham University Library, n.d.). offers a number of services for authors who think that the metric analysis of their work does not fully reflect their publication portfolio. The statement of Anne-Wil Harzing (2016) is also presented there Publish or Perish "Are you applying for tenure, promotion or a new job? Is your work cited in journals which are not ISI listed? Publish or Perish is designed to help individual academics to present their case for research impact to its best advantage."

This refers to Publish or Perish software you can download for free, which can search for, retrieve and then allow you to analyse citations to a set of publications. It uses citation data from Google Scholar and Microsoft Academic Search, and allows you to present a number of metrics based upon that data (https://harzing.com/popbook/toc.htm).

Despite the fact that the presence/absence of a publication in WoS or Scopus citation databases can hardly be regarded as a sign of its scientific significance, for an author-researcher to have a publication in a journal indexed in one of the databases (or both) is "vital." Therefore, one of the author's most popular questions for the librarian sounds something like this: "Which of the journals indexed by WoS or Scopus should I submit an article to?" The answer to such questions was the expansion of the range of services by libraries to assist user-authors, including the reveal of pseudoscientific journals (Nazarovets, Teixeira da Silva, \& Nazarovets, 2019).

A greater number of indicators of publication activity are based on two factors: the number of publications and the number of citations in a particular database. The correctness of accounting for these indicators is the main task for further evaluation of scientific activity and, at the same time, the ability of the library to strengthen its significance as an information and analytical centre of the university (Bychko, 2018; Yepifanova \& Savelieva, 2018; Kolesnykova, 2015; Kolesnykova \& Matveyeva, 2015).

The purpose of the article is to prove the possibility of increasing the significance of university libraries through the services of presenting the publication activity of a scientific organization based on the existing practices. 


\section{Methodology}

Consideration of the possibilities of the university library to support the scientific and publishing activities of the university, namely its publication activity, was carried out on the experience of Scientific and Technical Library of Dnipro National University of Railway Transport named after Academician V. Lazaryan.

Thus, the experience presented concerns Dnipro National University of Railway Transport named after Academician V. Lazaryan and its representation in the main international Scopus and Web of Science databases. Work in these global citation databases is possible only in English, therefore the organization profile is presented as Dnipro National University of Railway Transport named after Academician V. Lazaryan.

\section{Results and Discussion}

\section{Profile of Dnipro National University of Railway Transport named after Academician V. Lazaryan in Scopus.}

Scopus is the largest unified database containing abstracts of scientific papers and citation information for peer-reviewed scientific literature, with built-in tools for tracking, analysing and visualizing data (http://www.elsevierscience.ru/products/scopus/). Scopus database contains more than 8 million profiles of organizations, for the creation of which a complex algorithm for identifying the organization name and creating profiles based on a comparison of various Scopus parameters was used. If the name of the organization is indicated in the article correctly, then the article will automatically get into the organization's profile. In other cases, you need to correct the profile of the article's author.

In order for the number of publications in the organization profile to be displayed correctly, you must:

1. Indicate in the publication the correct profile of the organization. In our case, for Scopus database, this is Dnipro National University of Railway Transport named after Academician V. Lazaryan.

The library staff created and corrected the profile of our university, taking into account the maximum number of various possible names of the organization, of which there were more than 70 (Fig. 1).

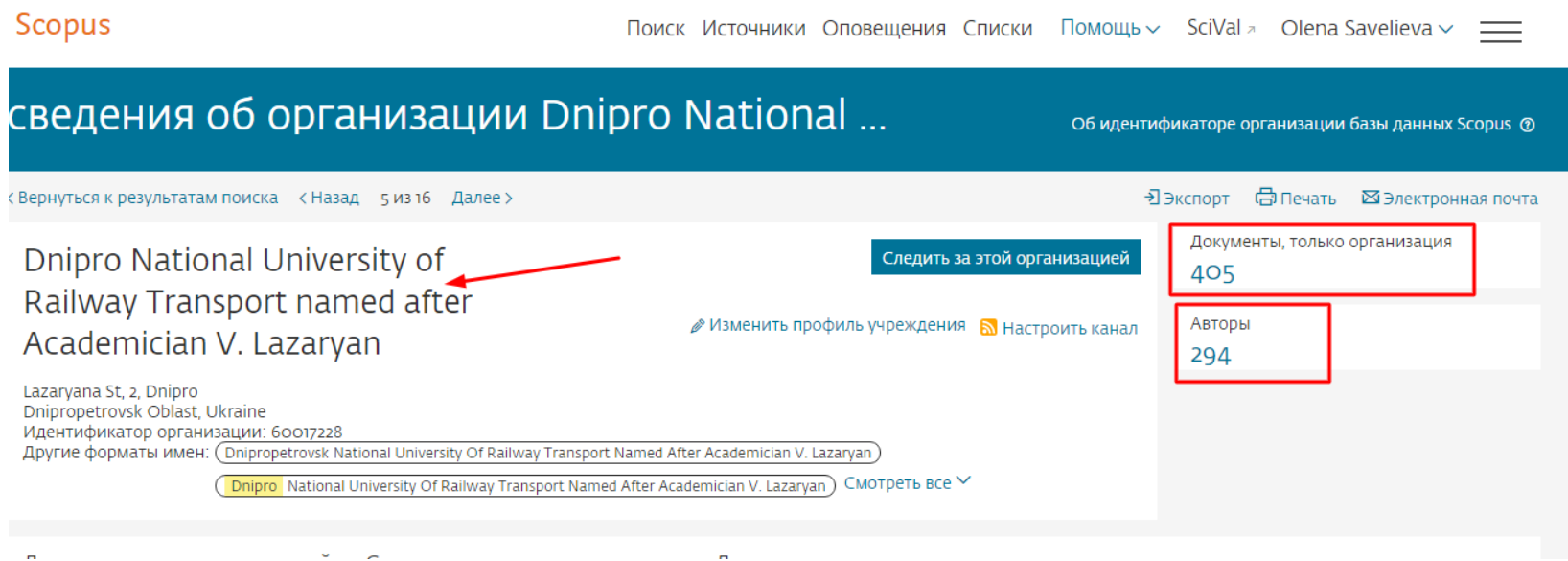

Fig. 1. University profile in Scopus database

Creative Commons Attribution 4.0 International https://doi.org/10.15802/unilib/2019_187559
(C) O. A. Savelieva, O. P. Savina, V. M. Stepanenko, O. V. Voitovych, 2019 56 
Today, in the profile of our organization there are more than 400 articles.

The profile was created and corrected in 2 stages:

1 stage - automatic profile creation;

2 stage - manual profile correction, taking into account the search for various organization spelling variants.

Scopus database has two options for manual correction of the organization profile:

- Using the Support Centre Form (Fig. 2):

https://ru.service.elsevier.com/app/contact/supporthub/scopuscontent/

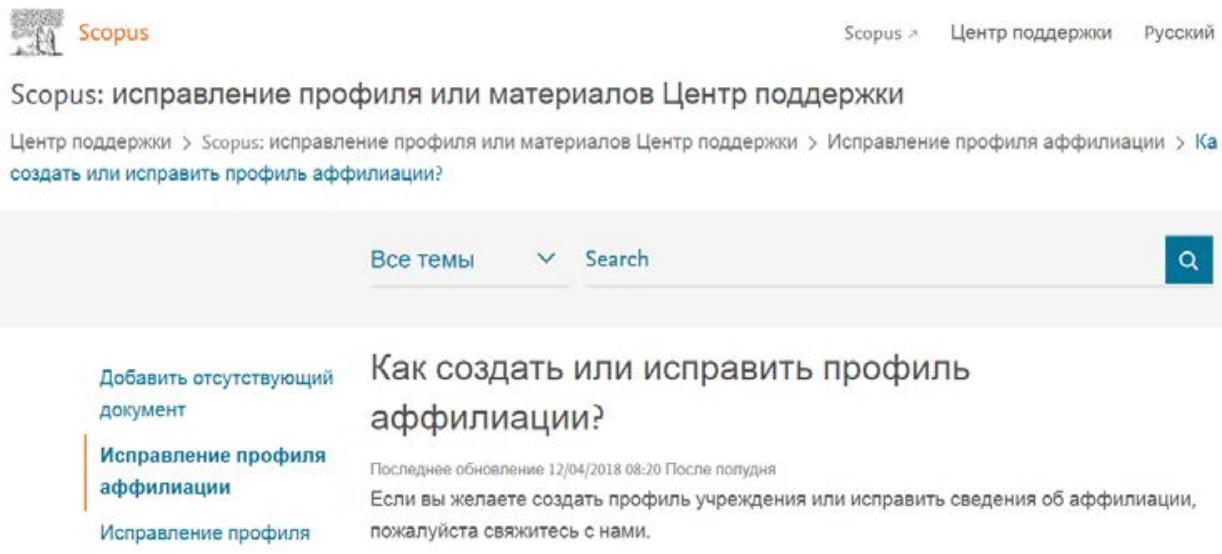

Fig. 2. Scopus database Support Centre Form for manual correction of the organization profile

- Using the Institution Profile Wizard.

Since, our organization has a subscription to Scopus database, we used the Institution Profile Wizard. To do this, the administrator of the organization must log in to Scopus database and send (English language is compulsory) the completed registration form (Scopus Institution Profile Wizard (IPW) Tool Administrator Registration Form) to affiliationfeedback@scopus.com with a request to activate access to the Institution Profile Wizard (Fig. 3).

Scopus Institution Profile Wizard (IPW) Tool Administrator Registration
Form
[22.12.2018]
[Dnipropetrovsk National University of Railway Transport named after Academician V. Lazaryan
(2 Lazarian St, Dnipro Dnipropetrovsk Region, Ukraine, AF-ID: 60017228)] submits to Elsevier, with
reference to the applicable Scopus Institution Profile Wizard Terms and Conditions* below and the
Elsevier Privacy Policy (https://www.elsevier.com/legal/privacy-policy) the following list of
Administrators for the Scopus Institution Profile Wizard (IPW) Tool.
\begin{tabular}{|l|l|l|}
\hline Name Administrator: & Scopus User Name: & $\begin{array}{l}\text { Effective Date of } \\
\text { Registration }\end{array}$ \\
\hline Olena Savelieva & Olena Savelieva & 10.10 .2018 \\
\hline & & \\
\hline & & \\
\hline & & \\
\hline & & \\
\hline & &
\end{tabular}

Fig. 3. Registration form for activating access to the Institution Profile Wizard

Creative Commons Attribution 4.0 International https://doi.org/10.15802/unilib/2019_187559
(C) O. A. Savelieva, O. P. Savina, V. M. Stepanenko, O. V. Voitovych, 2019 
After consideration and approval of the application, it becomes possible to correct the organization profile independently (available to the administrator). (Fig. 4).

Thus, the work on profile correction became possible with greater accuracy and efficiency

\section{Мастер профиля учреждения}

Просмотреть и изменить профиль для: Dnipro National University of Railway Transport named after Academician V. Lazaryan

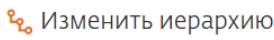

- изменить взаимосвязи организации

иерархии

- Добавить или удалить профили из иерархии

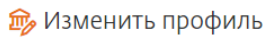

- Обновить данные об организации (предпочтительное название, адрес, веб-сайт) Добавить/удалить альтернативные названия организации
災 Создать профиль

- Указать подробные сведения об организации (предпочтительное название, адрес, веб-сайт)

- Добавить альтернативные названия организации

Fig. 4. Final work on correcting the university profile

2. For the correct display of the number of articles in the organization profile, you need to edit the author profile.

To do this, again two forms of automatic profile correction are used. The first is directly through the author's profile (Fig. 5).

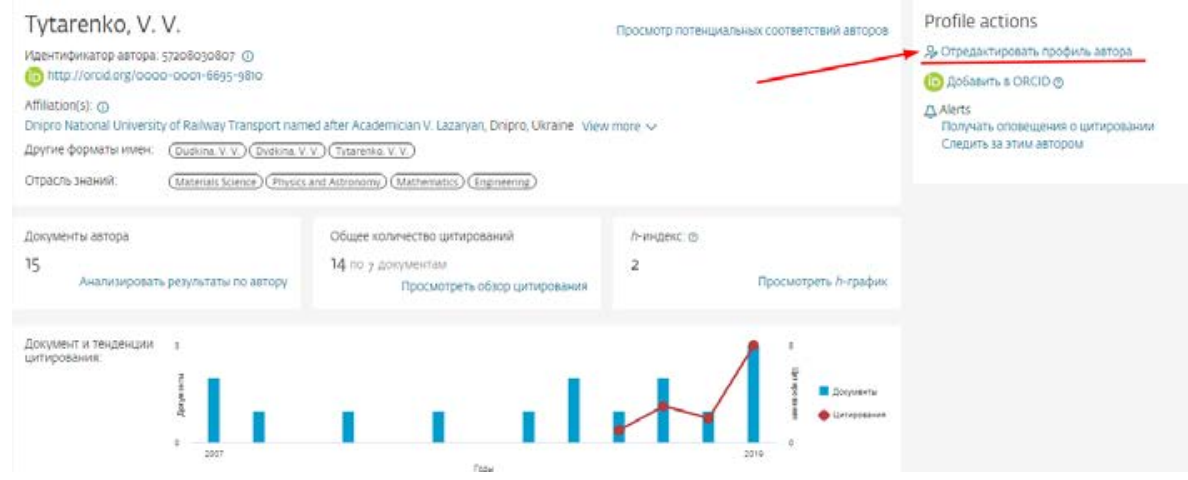

Fig. 5. Form for automatic profile correction directly through the author's profile

The second profile correction is through the Support Centre (Fig. 6):

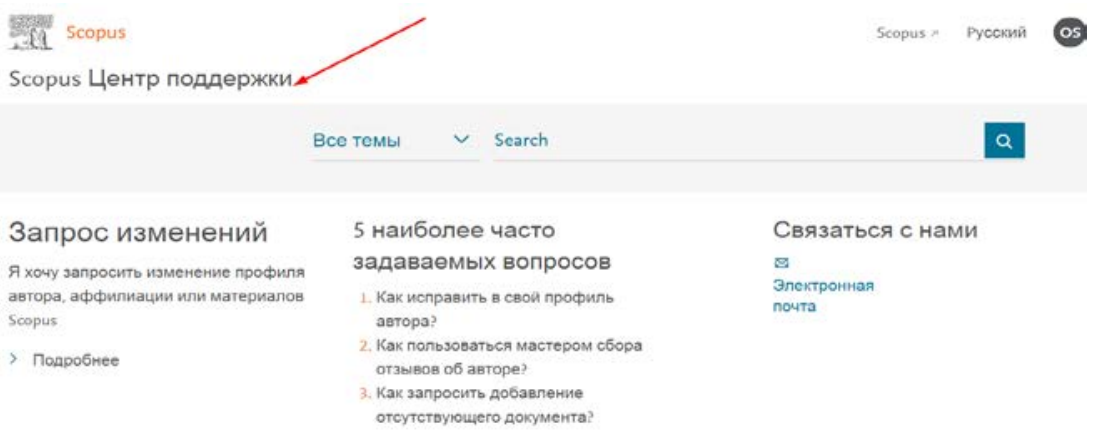

Fig. 6. Correction of the author profile through Support Centre

Creative Commons Attribution 4.0 International https://doi.org/10.15802/unilib/2019_187559
(C) O. A. Savelieva, O. P. Savina, V. M. Stepanenko, O. V. Voitovych, 2019 
Profile of Dnipro National University of Railway Transport named after Academician V. Lazaryan in Web of Science database.

Web of Science (WoS) is a bibliographic database created by Eugene Garfield, the founder of the Science Citation Index (SCI) in the 1950s and early 1960s. Now it is an Internet search platform combining abstract databases of publications in scientific journals and patents, including databases that take into account mutual citation of publications. Creating a university profile in (WoS) we used a similar approach as in Scopus. Namely, the collection of all variants of university names and the formation of correction request for the profile of Dnipro National University of Railway Transport named after Academician V. Lazaryan.

The request was created using the Customer Support Helpdesk (Fig. 7).

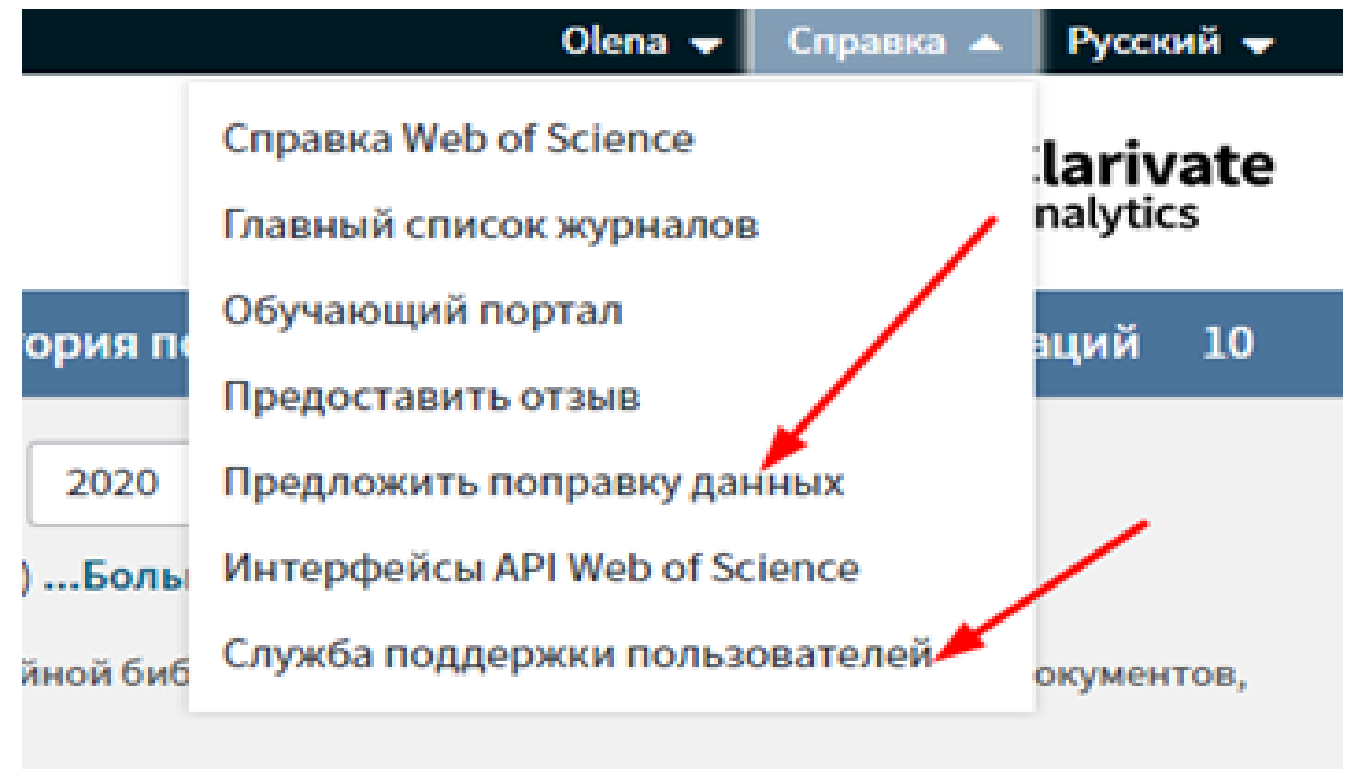

Fig. 7. Customer Support Helpdesk (WoS)

3. For correct display all the research achievements of the university, it is necessary to track and adjust the citation of articles, as well as to assist scientists in the basics of scientometrics, quantitative and qualitative characteristics of the scientist's productivity, scientific organization (h-index, SNIP, SJR, CiteScore, etc.). In this regard, scientific and practical seminars are held, explanatory work for profile correction is underway, and visualization of the scientific activities of scientists is being created on the library website.

The work of the University Library in the provision of such services has significantly improved the competence of both the university research staff and administrative specialists.

Below are the indicators of the university rating increase according to the version of Osvita.ua site "TOP 200 Ukraine" (https://ru.osvita.ua/vnz/rating/64884/) from 2015 to 2019. Indicators show increase in DNURT positions from 77-th position to the 58-th (Fig. 8). 


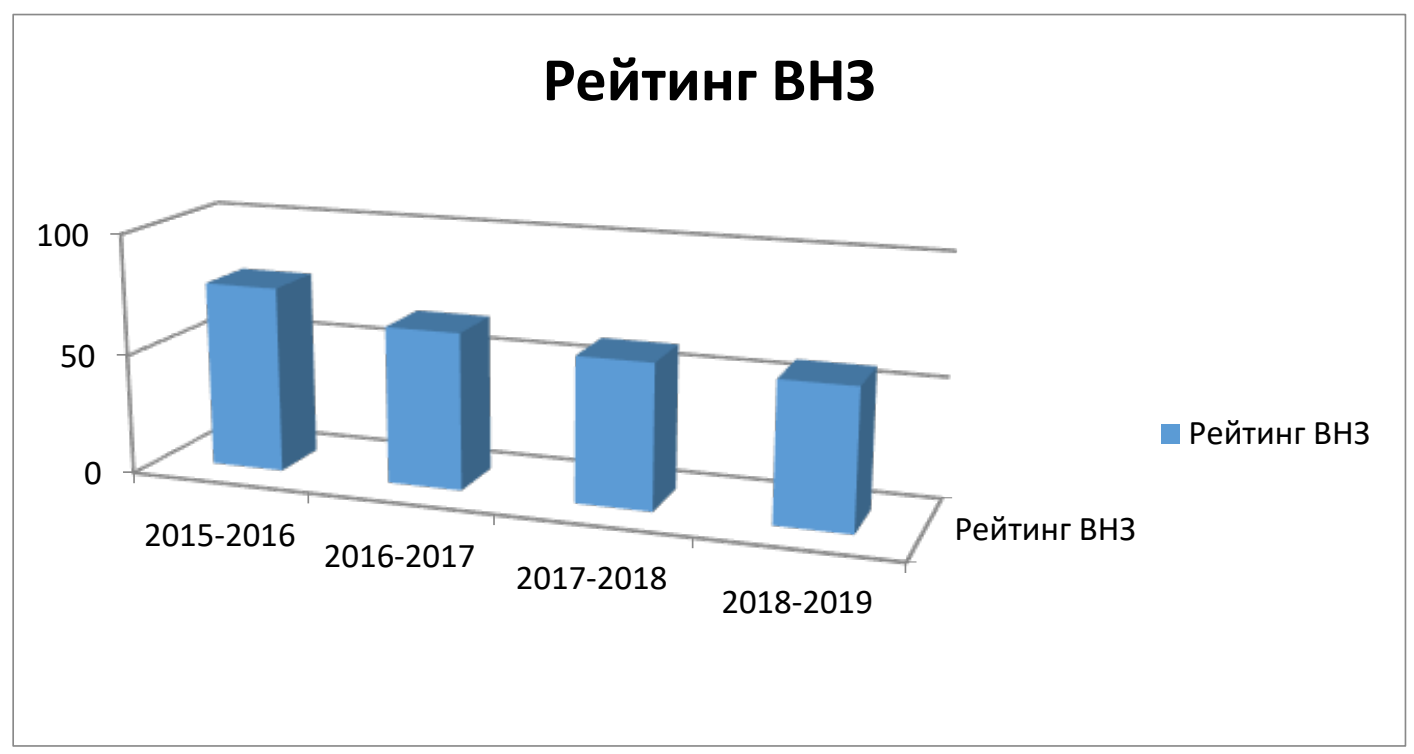

Fig. 8. Chart of indicators increase of university rating according to the version of Osvita.ua "TOP 200 Ukraine"

\section{Conclusions}

Thus, the role of the library in the development of scientometric research in the university cannot be underestimated. This is not only a transition to a qualitatively new stage of partnerships with scientists, but also new skills and qualifications, new knowledge and possibilities, new roles for librarians and university library.

\section{REFERENCES}

Bychko, O. M. (2018). Rolj biblioteky u naukometrychnykh doslidzhennjakh universytetu. Naukovi praci Kam'janecj-Podiljsjkogho nacionaljnogho universytetu imeni Ivana Oghijenka. Serija: Bibliotekoznavstvo. Knyghoznavstvo, 5, 149-153. Retrieved from http://nbuv.gov.ua/UJRN/npkpnuiobk_2018_5_28 (in Ukranian)

Durham University Library. (n.d.). Google Scholar: Publish or Perish. Retrieved from https://www.dur.ac.uk/library/research/evaluate/howdoi/publishperish/

Harzing, A.-W. (2016). Publish or Perish. Retrieved from https://harzing.com/resources/publish-or-perish

Kolesnykova, T. O. (2015). Trendy rozvytku bibliotek v universytetakh Ukrajiny ta svitu. Rozbudova ghromadjansjkogho suspiljstva: misija Ukrajinsjkoji bibliotechnoji asociaciji: zbirnyk materialiv Vseukrajinsjkoji naukovo-praktychnoji konferenciji, 18-19 lystopada 2015, Kyiv, 7-10. Retrieved from http://eadnurt.diit.edu.ua/jspui/handle/123456789/4326 (in Ukranian)

Kolesnykova, T. O., \& Matveyeva, O. V. (2015). Universytetsjka nauka: bibliometrychni doslidzhennja. Suchasni problemy dijaljnosti bibliotek $v$ umovakh informacijnogho suspiljstva: materialy mizhnarodnoji naukovo-praktychnoji konferenciji, 10-11 veresnja 2015, Lviv, 40-48. Retrieved from http://eadnurt.diit.edu.ua/jspui/handle/123456789/4173 (in Ukranian) 
Kolesnykova, T. O. (2016). Servisni sluzhby suchasnoji universytetsjkoji biblioteky: obslughovuvannja naukovciv. Bezpekove innovacijne suspiljstvo: vzajemodija u sferi pravovoji osvity ta pravovogho vykhovannja: Mizhnarodna internet-konferencija, 25 travnja 2016, Kharkiv. Retrieved from http://eadnurt.diit.edu.ua/-jspui/handle/123456789/4733 (in Ukranian)

Kvelidze-Kuznetsova, N. N., \& Morozova, S. A. (2009). Bibliometricheskie pokazateli kak otsenochnyy kriteriy deyatelnosti prepodavatelya universiteta. Universum: Vestnik Gertsenovskogo universiteta, 4, 38-45. Retrieved from https://cyberleninka.ru/article/n/bibliometricheskiepokazateli-kak-otsenochnyy-kriteriy-deyatelnosti-prepodavatelya-universiteta (in Russian)

Myamlin, S. V. \& Kolesnykova, T. O. (2014). Development of scientific school of transport mechanics: artistic legacy of Ye. P. Blokhin. Science and Transport Progress, 1 (49). 7-21. doi: https://doi.org/10.15802/stp2014/22657

Myrhorodska, A. I., \& Savelieva, O. A. (2016). Evolyutsiya bibliotechnoy deyatelnosti v protsessakh formirovaniya nauchnykh potentsialov universitetov. University's Library at a New Stages of Social Communications Development : Proceedings of the IIId International Scientific and Practical Conference, December 1-2, Dnipro, 2016.2 doi: https://dx.doi.org/10.6084/m9.figshare.4216920 (in Russian)

Nazarovets, S., Teixeira da Silva, J,. \& Nazarovets, M. (2019). Challenge of Ukrainian academic librarians in an evolving scholarly publishing landscape. The Journal of Academic Librarianship, 45 (1). 9-14. doi: https://doi.org/10.1016/j.acalib.2018.11.001

Yepifanova, O. V., \& Savelieva, V. V. (2018). Pidvyshhennja publikacijnoji aktyvnosti naukovciv universytetu : mozhlyvosti biblioteky. Naukovo-komunikacijnyj prostir biblioteky ZVO: vymoghy chasu ta realiji: vseukrajinsjka naukovo-praktychna konferencig, 1-2 lystopada 2018, Mykolaiv. Retrieved from http://dspace.snu.edu.ua:8080/jspui/handle/123456789/2467 (in Ukranian) 
САВЕЛЬЕВА О. А.

Науково-технічна бібліотека, Дніпровський національний університет залізничного транспорту імені академіка В. Лазаряна (Дніпро, Україна), e-mail ojs.stp@gmail.com, ORCID 0000-0001-7670-4483

CABIHA О. П.

Науково-технічна бібліотека, Дніпровський національний університет залізничного транспорту імені академіка В. Лазаряна (Дніпро, Україна), e-mail savina.o.p@gmail.com, ORCID 0000-0001-7872-6416

СТЕПАНЕНКО В. М.

Науково-технічна бібліотека, Дніпровський національний університет залізничного транспорту імені академіка В. Лазаряна (Дніпро, Україна), e-mail ctepsvi.diit@gmail.com, ORCID 0000-0003-2409-3769

ВОЙТОВИЧ О. В.

Науково-технічна бібліотека, Дніпровський національний університет залізничного транспорту імені академіка В. Лазаряна (Дніпро, Україна), e-mail olenka-a5@ukr.net

\section{ПРОФІЛЬ НАУКОВОЇ ОРГАНІЗАЦІї В БД SCOPUS, WЕВ ОF SCIENCE. РОЛЬ УНІВЕРСИТЕТСЬКИХ БІБЛІОТЕК У ПРЕДСТАВЛЕННІ ПУБЛІКАЦІЙНОЇ АКТИВНОСТІ НАУКОВОЇ ОРГАНІЗАЦІї}

Мета. Стаття має на меті довести можливість підвищення значущості університетських бібліотек через сервіси представлення видавничої діяльності наукової організації. Методика. Розгляд можливостей університетської бібліотеки для підтримки наукової та видавничої діяльності університету, а саме його видавничої діяльності, проводився на досвіді науковотехнічної бібліотеки Дніпровського національного університету залізничного транспорту імені академіка В. Лазаряна (бібліотека ДНУЗТ). Результати. Представлені особливості та етапи створення / корекції профілю організації в базах даних Scopus та Web of Science. Вказано роль бібліотеки в наукометричних дослідженнях, що оцінюють видавничу діяльність університету. Висновки. Попит на університетську бібліотеку та посилення ії ролі значно збільшився внаслідок впровадження послуг із підтримки видавничої діяльності працівників та організації.

Ключові слова: профіль організації; Scopus; Web of Science; бібліотека ДНУзТ; послуги 3 публікації; бібліотечні послуги

Creative Commons Attribution 4.0 International https://doi.org/10.15802/unilib/2019_187559
(C) O. A. Savelieva, O. P. Savina, V. M. Stepanenko, O. V. Voitovych, 2019 62 